\title{
R\&D Personnel Career Routes: An Exploratory Study
}

\author{
Barbara Bigliardi (I), Alberto Ivo Dormio (2)*
}

\begin{abstract}
This study, aiming at investigate the alternative modes of career development for personnel belonging to R\&D staff, addresses the extent to which career anchors are applicable to R\&D staff and to examine the relationship among career anchors, gender and age, with the final purpose to add elements of discussion to the long-lasting debate about this matter.With this purpose in mind, we developed a questionnaire survey among 309 R\&D personnel employed at firms belonging to the food machinery industry in a Northern Italy district. The results obtained from the statistical analysis indicate that the R\&D personnel's career orientations is a predictor of their career routes preferences, confirming three possible career routes in R\&D labs that were highlighted in previous studies.
\end{abstract}

Keywords: Career anchors, Career orientations, Food machinery industry, R\&D personnel.

* Industrial Engineering Department, University of Parma.Viale G.P. Usberti, I8I/A. 43100 Parma (ITALY)

(I) Barbara Bigliardi, Ph.D., Eng. E-mail: barbara.bigliardi@unipr.it, tel. +39 052I 905860, fax +39052I 905705

(2) Alberto Ivo Dormio, E-mail: albertoivo.dormio@unipr.it, tel. +39 052I 905853, fax +39 052I 905705 


\section{Introduction}

A review of the literature on $R \& D$ personnel suggests a wealth of studies related to their career paths and motivation, as a consequence of changes in terms of both economic and technological conditions, but also in terms of definition for work, careers and job structure (Frohman, 1978; Goldberg and Shenav, 1984; Allen and Katz, 1986, Miller, 1986; Baylin, I99I;Allen and Katz, 1992; Bridges, 1994; Cordero et al. 1994; Mc Cormick, 1995; Allen and Katz, 1995; Rifkin, 1995; Hall, 1996; Chen et al. 1999). Traditional career theories are becoming outdated as the hierarchical pyramids on which they are based. Previous studies identified salary and reward systems, lack of feeling of prestige, and the perceived opportunities for career advancement as the main aspects to be considered when dealing with R\&D satisfaction. However, little research has been conducted that focuses on the design of a career management system and on factors beyond demographics that may help to explain the career paths of these employees. Schein (1978) suggested that the concept of the career anchor was a practical means for guiding an individual's career through greater self-awareness of talents, motives, and abilities. Better understanding of the career orientation can help individuals make better career decisions and organizations make better placement decisions. Therefore, the focus of this study is first to verify the validity of Schein's career orientations inventory to the food packaging industry, second to examine the relationship between age, gender and career anchors. These problems are particularly relevant in public $R \& D$ organizations, where managing $R \& D$ professionals is critical.Typically this leads to hiring a large pool of engineers to benefit from their varied technical skills and to buffer against environmental change. Of all employees, those employed in R\&D function are often considered a strategic asset for their employers and this segment of the labor-force has to be carefully monitored.The shortfall in qualified labor associated with some industry makes professional career planning even more problematic, since organizations require the right mix of people and skills at the appropriate levels. Effective career management has to meet both organizational and individual needs (Schein, 1978), highlighting the importance of paying attention to engineers' career orientations (Igbaria et al., 1999).

Therefore, the purpose of this study is twofold: first, to verify the validity of Schein's career orientations inventory to the food machinery industry; second, to examine the relationship among career anchors, age and gender.

Two streams of literature inform the current study:

I) a brief explanation of Schein's theory of careers anchors;

2) on overview of career routes theories.
The remainder of the paper is organized in four sections. The next section provides a brief description and commentary on career anchors and career routes theories. As well as career management modes specific for R\&D personnel. Then the research methodology and the variables are described, followed by the results obtained from the statistical analysis. The final section analyses the main implications and conclusions that can be drawn, and provides some general commentary on the usefulness of the Schein's anchors in this context.

\section{Career anchors and career routes theories}

Edgar Schein (1978)conducted a longitudinal study (from I96 I to 1973) in which he assessed the career motivations, educational and occupational histories, work values and attitudes, values and self-concepts of 44 Master of Business Administration student at 5 years and approximately $10 \pm 12$ years after their graduation. The types of work these alumni were involved in encompassed a wide spectrum; from university professor to part owner of a family run furniture business. In studying these graduates, Schein found that although there was no consistency in their job histories, there was a great deal of similarity in the reasons for their career decisions. These career decisions seemed to follow patterns; thus, the concept of the career anchor was developed to describe the patterns. Schein defined the career anchor "the element in a person's self-concept, which he or she will not give up, even in the face of difficult choices" (1990).A career anchor has three components: (I) the individual's self-perceived talents and abilities, (2) the self-perceived motives and abilities of the individual, and (3) the attitudes and values the individual perceives that he or she to hold (Schein, 1978). Originally, he identified five patterns, or anchors, which explained the career decisions (Schein, 1978), whose names and description are the following:

I) Managerial competence anchor, defined by three items, indicates the willingness to integrate and coordinate other individuals' activities. People with this anchor tend to be accountable and responsible for the results of a process or function.

2) The main aim of people who have technical/functional competence anchor, defined by five items, is to use their technical skills in the particular areas they work. An individual with this anchor is interested in a job/task that provides him/her to enhance his or her capabilities.

3) Autonomy/independence anchor, defined by three items, is related to the aim of developing a career that provides autonomy to decide when, what on and how hard to work. Promotions or other rewards may even be sacrificed for autonomy that is of primary importance. 
4) Individuals anchored in security/stability, defined by three items, tend to acquire job security, stable income, and a certain future in the form of a good retirement program and benefits. Security is a twofold concept: one side of security is related with the job, the other side is related with the possibility of working in the same geographical area.

5) Individuals in the entrepreneurial creativity anchor, defined by three items, tend to possess the need to build or create something that is entirely their own product. Although the creation of a product or process is the key to these people's career anchor, they lose interest once the programs are up and running successfully.

Subsequent research (Derr, 1980; DeLong, 1982) added three more categories:

I) Service/dedication anchor, defined by two items, is about the achievement and respect for the specific individual and social values. The interpersonal competence and helping can be stated as ends in themselves rather than means to reach these ends.

2) Individuals in the pure challenge anchor, defined by three items, are typical of respondents who look for job novelty, variety and tasks ensuring challenge and emotional commitment.

3) Life style profile, defined by three items, provides a measure of the degree of balancing the identity of the respondent, his or her family and the organization.

In analyzing the five anchors, it could be argued that individuals may have more than one anchor. Indeed, in a follow-up survey of other managers, Schein (1978) found that the managers could not classify themselves into a single group. It is expected however, that in most cases, a single anchor will dominate in the career decisions of the individual.

An important element of effective management of R\&D professionals is the design of a career-management system, to satisfy employees' career values and aspirations and to make sure the organization has the right mix of people, with the right mix of skills, at the appropriate organizational level (Greenhaus and Callanan, 1994).

The career anchor is significant because it influences career choices, affects decisions to move from one job to another, shapes what is being looked for in life, determines an individual's views of the future, influences the selection of specific occupations and work settings, and affects employees' reactions to their work experiences (Schein, 1978). It has been suggested that career success, measured by low turnover and high satisfaction and commitment levels, is achieved through a better un- derstanding of individuals' needs on the job and their orientations to their work. Other studies also suggested that career orientation influences career success (Gould and Penley, 1984; Aryee, 1992). A measure of career orientation enables an organization to find a match between organizational and individual needs and to restructure jobs accordingly. It also serves as a useful information base for individuals contemplating career changes, and for organizations seeking to help individuals plan their careers (DeLong, 1982; Igbaria et al., I991;Aryee, 1992).

The need for appropriate career management systems for industrial researchers has been much debated in both industrial and academic circles (Allen and Katz, 1986, 1992; Aryee and Leong, 1991; Badawy, 1988; Bailyn, 1991; Goldberg and Shenhav, 1984; Miller, 1986; Realin, 1987; Shephard, 1988; Smith and Szabo, 1977; Tampoe, 1993; von Glinow, 1988). Probably the best known, and perhaps the most controversial, career system for technical professionals is the "dual ladder" system (Allen and Katz, 1986, 1992). This is a system where R\&D professionals can remain employed as engineers and scientists instead of being forced into the lucrative managerial path once they are perceived to be performing excellently as engineers and scientists. Benefits arising from the adoption of a dual ladder system are ambiguous: many companies that do not have a dual ladder career system believe they have missed an important asset to motivate their technical professionals, while companies that have a formal dual ladder system often question its contribution (Debackere et al., 1997). Notwithstanding it's problems pointed out by Allen and Katz (1986), several researches show that for part of the organization's R\&D staff the technical ladder systems opens up interesting career development perspectives (Bailyn, 1991;Allen and Katz, 1986, 1992; Debackere et al., 1997). Nevertheless, the same studies revealed the necessity of exploring alternative career routes. As for the career routes, Bailyn (199I) suggested three possible routes:

I) the managerial route: this route slowly moves a person away from technical work, and it is the most usually described as "successful" path and the more attractive one because it carries with it the highest compensation and prestige and often provides R\&D staff with the possibility to have real influence on technical work;

2) the technical route: employee progresses while still remaining involved in technical work;

3) the project career: in this route, employees are engaged in challenging and exciting activities and projects irrespective of promotion.

Among the career routes above listed, the movement from project career is less explicit. Previous studies (Jewkes et al., 
1979;Allen and Katz, 1992) demonstrated that this route is preferred by employees that are older, with a lower education and characterized by a long job tenure.

\section{The research methodology}

The research at the basis of the present study is mainly composed by two phases: a preliminary literature review and a parallel discussion with experts belonging to the industry under investigation, and, as result of the precedent two phases, a questionnaire survey. The field research, developed through focus group with both managers and academics, consisted of interviewing about the prevailing human resource management practices adopted for technical professionals. This allowed to explore the dynamics of, and prospects for the career development for scientists and engineers in the specific context investigated, and to build a framework for the questionnaire survey.

The research design employed in this study was a postal survey. Data were collected over two semesters in 2007 , on a sample of $5 \mathrm{I}$ firms belonging to the food machinery industry throughout northern Italy. The choice of this specific industry is motivated by two main reasons: (i) the fact that these manufacturers represent the backbone of some local economies of northern Italy, with approximately $85 \%$ of production being sold abroad, and (ii) the importance that the machinery-building manufacturing environments are gaining in terms of R\&D issues. The firms selected for the survey belong to a database previously realized by the same authors of this paper and utilized for previous research on the theme of innovation, composed by $20 \mathrm{I}$ firms of the same sectors.Among the 98 firms (out of 20I) that agreed to participate to our researches, a total of $5 \mathrm{I}$ firms were comprised in the final sample, that is the $5 \mathrm{I}$ firms that have a R\&D function, for a total of 309 R\&D employees.

In order to provide more complete information and render the preliminary version of the questionnaire valid, "round-table" meetings were organized with six managers directly responsible for the R\&D unit. Each manager reviewed the proposed questionnaire to clarify any confusing terms or concepts.All six reviewers indicated they found the questionnaire very through and the R\&D personnel would have no problem providing all the requested information. The instrument was then pre-tested by a small convenience sample of R\&D employees. This stage provided to be particularly useful since it provided a direct insight into how specific phenomena which came to the fore during the literature review found actual application in the industrial practice within the context under investigation. The results of this process were edited for overlaps and repetitions to produce a final questionnaire. The questionnaire was accompanied by a statement indicating the purpose of the study.
The statement also assured complete confidentiality to the respondents. As an incentive to complete the questionnaire, the respondents were promised a summarized copy of the results.

Respondents were asked to gauge the extent they agreed with any of the several statements concerning their career routes and management. All items were formulated as short statements on a seven-point Likert scale. The data for this study were obtained by using a questionnaire. The questionnaire was divided into three parts:

I) Background variables: general information about the firm he/she belong to (organizational structure, dimension, etc.), and about the respondent (gender, education, job tenure, age), The influence of demographic variables on careers was examined in different studies: age (Allen and Katz, 1992); gender (Bailyn, 1982; Igbaria et al., 199I); education (Taylor, 1979; Allen and Katz, 1992); and professional tenure (Reilly and Orsak, 1991; Lynn et al., 1996). Reviewing the above literature, the first part of the questionnaire included a series of self-reported questions about background variables, such as age, gender, education and professional tenure.Age was a self-reported question. Gender was coded as I = male and $2=$ female. As for education, it was asked if the respondents hold a degree, a Ph.D or a Master. Professional tenure was coded on the basis of three career stages: establishment (two years or less) $=\mathrm{I}$, advancement (over two and up to ten years) $=2$ and maintenance (over ten years) $=3$.

2) Career orientations: the 40 items drawn from the original questionnaire by Schein (1978), rated on a five-point Likert scale, were used to measure the eight career anchors of R\&D professionals.

3) Career preferences: this section included five questions about career mobility that are taken into account as a possible career track. Career path items were developed by reviewing similar studies (Allen and Katz, 1986; Debackere et al., 1997). The questions about career path preferences were rated on a five-point Likert scale (where I =not at all and $5=$ to a very large extent).

The items of section two and three were written to operationalize the constructs of interest. Questions measuring career preferences are reported in Table I: 


To what extent would you like your career to be:
a. A progression up the managerial ladder to a higher-level position
b. A progression up the technical professional ladder to a higher-level
position
c. The opportunity to engage in those challenging and exciting research
activities and projects, irrespective of promotion
d. A. horizontal sequence of activities in the product development process
downstream from your current activity
e. A. horizontal sequence of activities

Table I - Questions measuring career preferences (on a five-point Likert scale)

\section{Analysis}

The questionnaires were sent to 309 individuals staffed in R\&D units and, after two follow-up, 169 were returned, of them 166 were found usable which yields a total response rate of 53.7 per cent. This response rate can be stated as fine. Baruch (1999) found that the average response rate was 55.6 with a standard deviation of 19.7 in managerial and behavioural sciences. In order to check for the severity of non-response bias, the means of the late respondents were compared with the means of the early respondents, for a number of demographic and model variables. Tables II and III show the demographic characteristics of respondents and general characteristics (in terms of dimension) of firm where these respondents are employed. Out of the 166 respondents, $32.5 \%$ were female $(n=54)$ and $67.5 \%$ were male $(n=\mid 12)$. All respondents hold a university degree, and fourteen percent had a P.h.D. degree. Only 10 respondents $(6 \%)$ hold a Master degree. The average age of the respondent was 42.5 years (s.d. $=8.16$ years) and the median age was $39-40$. On average, the respondents had been with their current job and had spent with the firm 15 years (s.d. = II.7 years) and 13.1 years (s.d. $=7.2$ years) respectively. Nineteen percent of respondents $(n=32)$ currently hold a management position, $50 \%(n=83)$ are assigned to a project team, the rest $(n=5 I)$ have a technical position without being assigned to a specific project or without holding managerial responsibilities. Finally, fifteen percent of the respondents describe their current work as purely research oriented, thirty-eight percent as purely development oriented and the remaining $\mathrm{I} 4 \mathrm{I}$ respondents $(53 \%)$ describe their work as a mix of research and development activities.

\begin{tabular}{|l|c|c|}
\hline Gender & $N$ & $\%$ or s.d. \\
\hline Male & 112 & $67.5 \%$ \\
\hline Female & 54 & 32.5 \\
\hline Educotion & & \\
\hline Graduate degree & 166 & $100 \%$ \\
\hline Ph.D. & 23 & $14 \%$ \\
\hline Master & 10 & $6 \%$ \\
\hline Age (in years) & 42.5 & 8.16 \\
\hline Job tenure (in years) & 15 & 11.7 \\
\hline Organizational tenure (in years) & 13.1 & 7.2 \\
\hline
\end{tabular}

Table II - Demographic characteristics of the sample 


\begin{tabular}{|l|c|}
\hline Turnover & $n$ \\
\hline$\leq 2 \mathrm{mln} €$ & 1 \\
\hline $2 \div 10 \mathrm{mln} €$ & 23 \\
\hline $10 \div 25 \mathrm{mln} €$ & 25 \\
\hline $25 \div 50 \mathrm{mln} €$ & 2 \\
\hline$\geq 50 \mathrm{mln} €$ & 0 \\
\hline Employees & 1 \\
\hline $1 \div 9$ & 34 \\
\hline $10 \div 49$ & 13 \\
\hline $50 \div 149$ & 3 \\
\hline $150 \div 249$ & 0 \\
\hline$\geq 250$ & \\
\hline
\end{tabular}

Table III - General characteristics of the firms belonging to the sample

As far as statistical analysis is concerned, an exploratory factor analysis with varimax rotation was conducted in order to determine the factor structure which underlies the career anchor typology. As confirmation of the usefulness of this type of analysis, Bartlett's test of sphericity and the Kaiser-Meyer-Olkin (KMO, it has to assume a value al least $>.5$ to be considered acceptable) measure of sampling adequacy were employed (Field, 2000).

The factor analysis produced eight factors with eigenvalues greater than or equal to I that accounted for 82.3 percent of the total variance. Examination of the initial factor results revealed that factors corresponded very closely to eight of Schein's career anchors. The homogeneity of items within each factor was established by computing their internal consistency reliability scores, by applying the formula of alpha coefficient proposed by Cronbach (195I). In Table IV the results of factor analysis are shown.

\begin{tabular}{|l|l|c|}
\hline Constructs & Items & Loads \\
\hline \multirow{5}{*}{ Managerial competence - MC } & $\begin{array}{l}\text { I am most fulfilled in my work when I have been able to integrate and } \\
\text { manage the efforts of others }\end{array}$ & .65 \\
\cline { 2 - 3 }$(a=0.75)$ & $\begin{array}{l}\text { I dream of being in charge of a complex organization and making de- } \\
\text { cisions that affect many people }\end{array}$ & .72 \\
\cline { 2 - 3 } & $\begin{array}{l}\text { I will feel successful in my career only if I become a general ma-nager } \\
\text { in some organization }\end{array}$ & .70 \\
\cline { 2 - 3 } & $\begin{array}{l}\text { Becoming a general manager is more attractive to me than becoming } \\
\text { a senior functional manager in my current area of expertise }\end{array}$ & .82 \\
\cline { 2 - 3 } & $\begin{array}{l}\text { I would rather leave my organization than accept a job that would take } \\
\text { me away from the general managerial track }\end{array}$ & $.42^{*}$ \\
\hline
\end{tabular}


J.Technol. Manag. Innov. 2009, Volume 4, Issue I

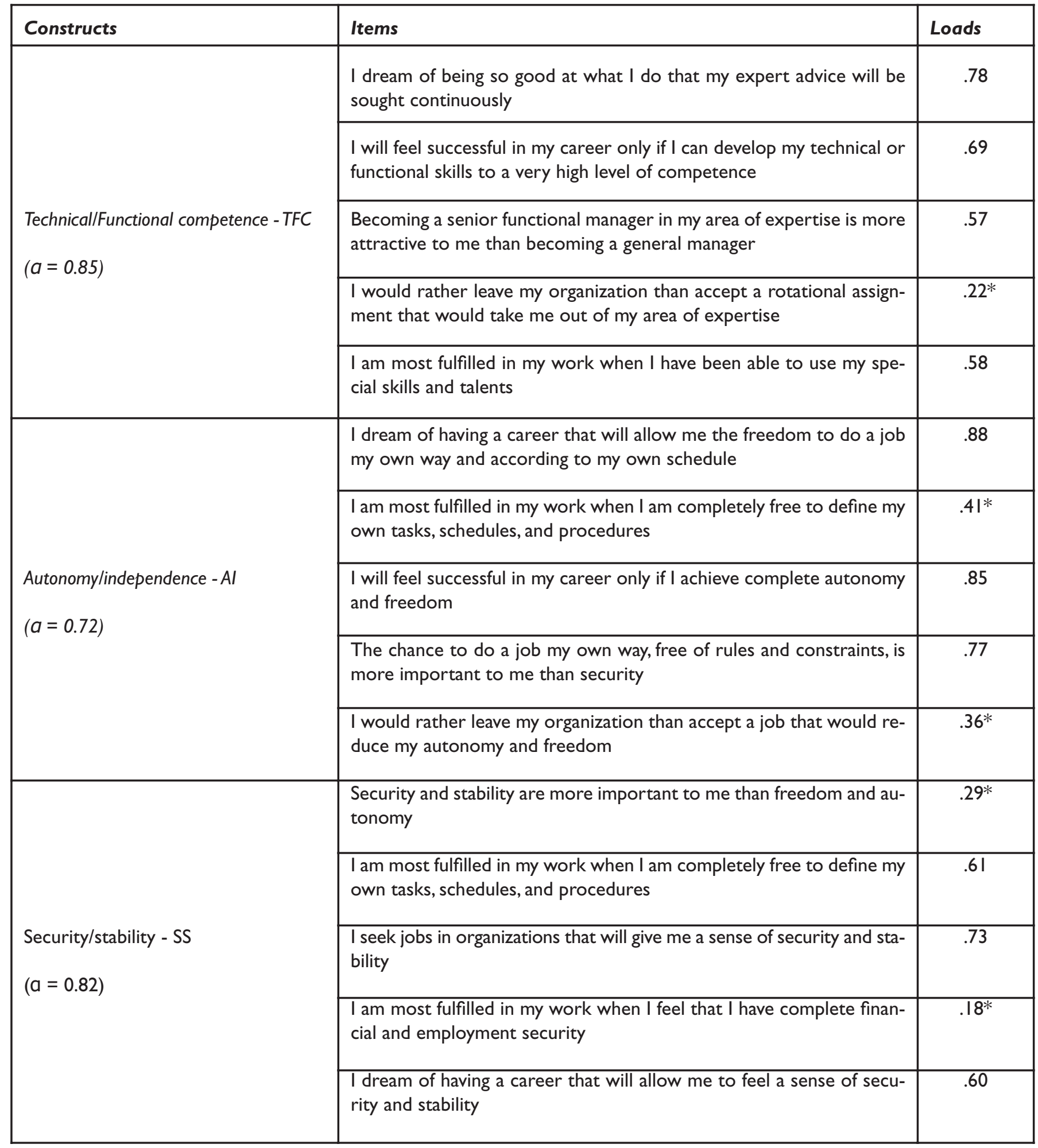


J.Technol. Manag. Innov. 2009, Volume 4, Issue I

\begin{tabular}{|c|c|c|}
\hline Constructs & Items & Loads \\
\hline \multirow{5}{*}{ Entrepreneurial creativity - EC } & $\begin{array}{l}\text { I am always on the lookout for ideas that would permit me to start my } \\
\text { own enterprise }\end{array}$ & .78 \\
\hline & $\begin{array}{l}\text { Building my own business is more important to me than achieving a } \\
\text { high-level managerial position in someone else's organization }\end{array}$ & .74 \\
\hline & I dream of starting up and building my own business & $.26 *$ \\
\hline & $\begin{array}{l}\text { I am most fulfilled in my career when I have been able to build some- } \\
\text { thing that is entirely the result of my own ideas and efforts }\end{array}$ & $.35^{*}$ \\
\hline & $\begin{array}{l}\text { I will feel successful in my career only if I have succeeded in creating } \\
\text { or building something that is entirely my own product or idea }\end{array}$ & .71 \\
\hline \multirow{5}{*}{ Service/dedication - SD } & $\begin{array}{l}\text { I will feel successful in my career only if I have a feeling of having made } \\
\text { a real contribution to the welfare of society }\end{array}$ & .77 \\
\hline & $\begin{array}{l}\text { I am most fulfilled in my career when I have been able to use my ta- } \\
\text { lents in the service of others }\end{array}$ & .65 \\
\hline & $\begin{array}{l}\text { Using my skills to make the world a better place to live and work in is } \\
\text { more important to me than achieving a high-level managerial position }\end{array}$ & .68 \\
\hline & $\begin{array}{l}\text { I dream of having a career that makes a real contribution to humanity } \\
\text { and society }\end{array}$ & $.39 *$ \\
\hline & $\begin{array}{l}\text { I would rather leave my organization than accept an assignment that } \\
\text { would undermine my ability to be of service to others }\end{array}$ & $.4 I^{*}$ \\
\hline \multirow{5}{*}{ Pure challenge - PC } & $\begin{array}{l}\text { I dream of a career in which I can solve problems or win out in situa- } \\
\text { tions that are extremely challenging }\end{array}$ & .84 \\
\hline & $\begin{array}{l}\text { I will feel successful in my career only if I face and overcome very dif- } \\
\text { ficult challenges }\end{array}$ & .89 \\
\hline & $\begin{array}{l}\text { I have been most fulfilled in my career when I have solved seemingly } \\
\text { unsolvable problems or won out over seemingly impossible odds }\end{array}$ & .96 \\
\hline & $\begin{array}{l}\text { I seek out work opportunities that strongly challenge my problem- } \\
\text { solving and/or competitive skills }\end{array}$ & .70 \\
\hline & $\begin{array}{l}\text { Working on problems that are almost unsolvable is more important } \\
\text { to me than achieving a high level managerial position }\end{array}$ & $.7 \mathrm{I}$ \\
\hline
\end{tabular}


J.Technol. Manag. Innov. 2009, Volume 4, Issue I

\begin{tabular}{|c|c|c|}
\hline Constructs & Items & Loads \\
\hline \multirow{5}{*}{$\begin{array}{l}\text { Life style - LS } \\
(a=0.5 I)\end{array}$} & $\begin{array}{l}\text { I would rather leave my organization than be placed in a job that would } \\
\text { compromise my ability to pursue personal and family concerns }\end{array}$ & .82 \\
\hline & $\begin{array}{l}\text { I dream of a career that will permit me to integrate my personal, fa- } \\
\text { mily, and work needs }\end{array}$ & .89 \\
\hline & $\begin{array}{l}\text { I feel successful in my life only if I have been able to balance my per- } \\
\text { sonal, family, and career requirements }\end{array}$ & .78 \\
\hline & $\begin{array}{l}\text { Balancing the demands of personal and professional life is more im- } \\
\text { portant to me than achieving a high level managerial position }\end{array}$ & .71 \\
\hline & $\begin{array}{l}\text { I would rather leave my organization than accept a job that would take } \\
\text { me away from the general managerial track }\end{array}$ & .93 \\
\hline
\end{tabular}

Table IV - Factor analysis

* These items were omitted due to a low loading $(<0.6)$ on the relative factor

Some items have been omitted due to a low loading $(<.6$, The factor labelled as "Entrepreneurial Creativity" comprised Guadagnoli and Velicier, 1988) on the relative factor. As a consequence of these eliminations, the final number of items considered in the analysis was 30 .

The first factor, managerial competence (MC), consisted of four items and had an internal consistency reliability of the scale equal to .90 .

Also the second factor consisted of the four items developed by Schein to measure technical/functional competence (TFC). The scale had an internal consistency reliability coefficient of 85 .

Another factor consisted of the three items related to the autonomy or independence anchor. The Cronbach alpha coefficient for this scale was .72 .

A factor consisted of three items related to security/stability three factors. The internal consistency reliability (coefficient alpha) of the three-item scale was .75 .

Three items measured the factor named "service/dedication", with a Cronbach alpha equal to .74 .

A factor consisted of five items related to "pure challenge". The internal consistency reliability of the five-item scale as used in this study was .66 .

Finally, a factor included five items identified by Schein as reflecting a "life style" anchor.The alpha reliability of the five-item scale was .5I.

Figure I shows that Service/Dedication is the most frequent career anchor in the sample, characterizing about $28 \%$ of the respondents. 


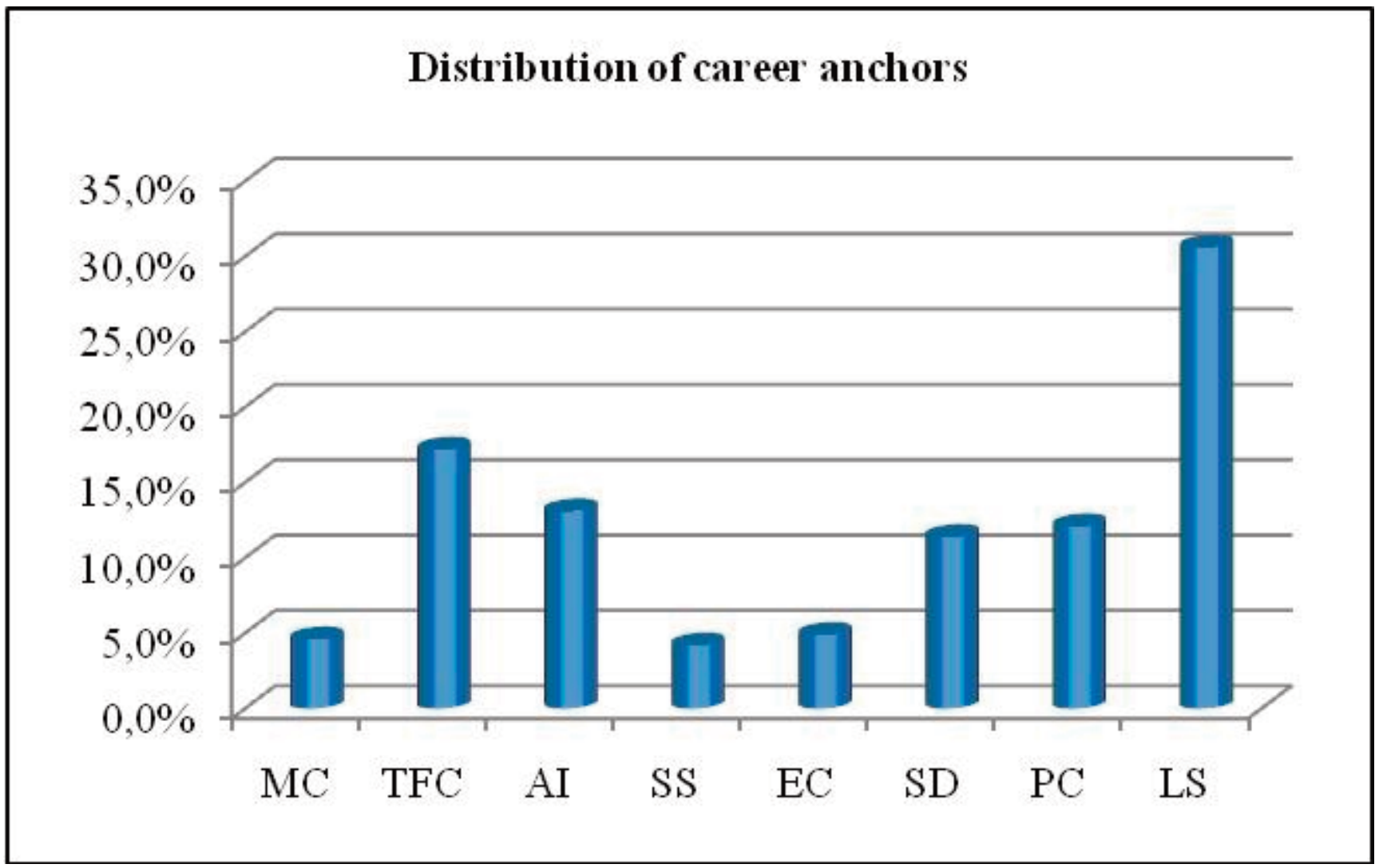

Figure I - The distribution of career anchors in the sample (percentage)

As for the career routes proposed in Table I, on 166 respondents, 139 expressed a clear preference for one of the career tracks. Specifically, 34 respondents $(24.5 \%)$ prefer a managerial career, $85(61.5 \%)$ a technical career, and the remaining 20 re- spondents (14\%) prefer a project to project career. This is in accordance with the actual position of respondents in the organization, with exception of project team members, as shown in Table V.

\begin{tabular}{|l|c|c|c|}
\hline & \multicolumn{3}{|c|}{ Career routes } \\
& \multicolumn{3}{|c|}{ preferences } \\
\hline \multicolumn{1}{|c|}{ Current position } & MR & TR & PR \\
\hline Manager & $68.2 \%$ & $25.3 \%$ & $6.5 \%$ \\
\hline $\begin{array}{l}\text { Technical } \\
\text { specialist }\end{array}$ & $9.8 \%$ & $76.1 \%$ & $14.1 \%$ \\
\hline Project member & $23.1 \%$ & $58.8 \%$ & $18.1 \%$ \\
\hline
\end{tabular}

Table V - Career routes' distribution controlling for position 
In addition, we studied the correlations between the three career routes considered previously (technical, managerial and project route) and the eight Schein's career anchors. Results are summarized in Table VI.As can be seen in this table, the managerial route is strongly positively correlated with the anchors MC, Managerial competence, EC, Entrepreneurial creativity, and PC, pure challenge, but negatively correlated with Technical functional competence anchor (TFC) and Security/stability an- chor. As far as the technical route is concerned, it is positively correlated with both Technical functional $(r=0.23, p<.00 I)$ and Life style $(r=0.33, p<.01)$ anchors, but negatively correlated with the Managerial competence anchor $(r=-0.36 p<$ $.00 \mathrm{I})$. Finally, the project route is correlated positively with the Technical functional anchor $(r=0.29, p<.001)$, but negatively with the Managerial competence one $(r=-0.19, p<.01)$.

\begin{tabular}{|c|c|c|c|c|c|c|c|c|c|c|c|}
\hline & I.MR & 2.TR & 3. PR & 4.MC & 5. TFC & 6. Al & 7.55 & 8. EC & $9.5 \mathrm{D}$ & 10. PC & II. LS \\
\hline I.MR & 1.00 & & & & & & & & & & \\
\hline 2. TR & $-.31^{* *}$ & 1.00 & & & & & & & & & \\
\hline 3. PR & $-.27^{* *}$ & .05 & 100 & & & & & & & & \\
\hline 4. MC & $.29 * *$ & $-.36^{* *}$ & $-.19 \%$ & 100 & & & & & & & \\
\hline 5. TFC & $-.72^{\text {w* }}$ & $.23^{* * *}$ & $.29^{* *}$ & $-.26^{*}$ & 1.00 & & & & & & \\
\hline 6. AI & -.12 & .10 & .02 & $.45^{\text {क* }}$ & -.09 & 100 & & & & & \\
\hline 7.55 & -.29 ** & .18 & .06 & $.39 \%$ & -.12 & $.23^{*}$ & 100 & & & & \\
\hline 8. EC & $.28^{* *}$ & .06 & .18 & -.09 & $.31 *$ & .16 & $.28^{*}$ & 100 & & & \\
\hline $9.5 \mathrm{D}$ & .19 & .18 & .15 & -.06 & $.40^{*}$ & .15 & .01 & $.41^{* * *}$ & 100 & & \\
\hline $10 . \mathrm{PC}$ & $.33^{* *}$ &.$\infty$ & .05 & -.02 & $.50^{\text {** }}$ & $.30^{*}$ & .04 & $.24 * *$ & -.01 & 1.00 & \\
\hline TI. LS & -.18 & $.33^{*}$ & -.01 & $.30^{*}$ & -.15 & -.11 & $.48^{* *}$ & .15 & .05 & $.43^{* *}$ & 100 \\
\hline
\end{tabular}

Table VI - Correlations between career routes and career anchors $\left(* \mathrm{p}<.0 \mathrm{I}\right.$; $\left.{ }^{* *} \mathrm{p}<.00 \mathrm{I}\right)$

Finally, in order to investigate the relationship between age, gender and the careers anchors, Pearson's correlations were undertaken. There was a significant correlation between age and Security/stability anchor $(t=3.18)$, age and Autonomy/independence anchor $(t=2.16)$ and age and Technical/functional $(t$ $=4.82$ ), all significant at the $p<0.000 \mathrm{I}$. The results of relationship between gender and career anchors are shown in TableVII
$(X 2=99.9, P=.001)$. It shows significant differences between the genders in all but two career anchors (the technical functional and service and dedication one). The proportion of women is significantly higher than that of men in the lifestyle anchors $(38.5 \%$ versus $22.7 \%, p=.000)$. In the other five anchors, the proportion of men to women is significantly higher. 


\begin{tabular}{|c|c|c|c|}
\hline & \multicolumn{2}{|c|}{ Gender } & \\
\hline $\begin{array}{c}\text { Career } \\
\text { anchors }\end{array}$ & Female (n= & Male (n= & (two-tailed) \\
\hline MC & 2.1 & II2) & \\
\hline TFC & 17.2 & 17.2 & .000 \\
\hline AI & 11.1 & 15.0 & .000 \\
\hline SS & 5.1 & 3.2 & .012 \\
\hline EC & 2.7 & 7.1 & .048 \\
\hline SD & 11.9 & 10.9 & .000 \\
\hline PC & 9.4 & 14.8 & .346 \\
\hline LS & 38.5 & 22.7 & .000 \\
\hline
\end{tabular}

Table VII - Preferred career anchors and gender

\section{Discussions and conclusions}

The objective of this exploratory study was to adapt Schein's Career Anchor Inventory to the careers of R\&D personnel employed in the food packaging industry, gaining some further insights into their career route preferences. Schein's identification of eight career anchors remained consistent within this research. This study identifies Lifestyle anchor as being the first most important career anchor across age and gender for most respondents, and technical functional career as the second most valued career anchor.

As far as the possible career routes are concerned, it emerges that R\&D professionals currently employed in a managerial position still view this route as the most desirable one, followed by a technical responsibilities and project as last preferred route. Technical specialists would prefer a technical ladder system and, to a lesser extent, a project one. Finally, project members strangely seem to prefer a technical career over a project career.

A second set of results points out that R\&D employees can not be classified as managerial in their career aspirations and orientations, since the Managerial competence anchor resulted the less important for respondents. Thus, organizations need to recognize the diversity of career orientation in order to develop and adopt appropriate career system management and reward systems.
Finally, the study emphasized also that a significant correlation exist between what an individual expects from his/her job and the career route he/she will follow. This is a confirmation that the instruments adopted to assess career orientation is a reliable one.

As far as managerial implications are concerned, the study can add further elements to the long-lasting debate about the dual ladder system. Specifically, results show that a greater articulation of roles, such as career opportunities, should be achieved, in order to overcome the too formalized ladder system.

We recognize some limitation of our study. The most important one is that it consider an homogeneous sample, both in terms of respondents (R\&D employees) and organizations (all firms, in fact, belong to the same industry). To overcome this limitation and address recommendation by Feldman and Bolino (1996), the next step of the research consists of the examination of career anchors in a large heterogeneous sample (research is incoming). Furthermore, Baruch (2004) suggests an emergence of three new factors in the twenty-first century. Future research should investigate the number and type of anchors. 


\section{References}

ALLEN, T.J. \& Katz, R. ( I 986). The dual ladder: motivational solution or managerial delusion?, R\&D Management, I6, 2, I85197.

ALLEN, T.J. \& Katz, R. (1992). Age, Education and Technical Ladder, IEEE Transactions on Engineering Management, 39, 3, 237 245.

ALLEN, T.J. \& Katz, R. (1995). The project-oriented engineer:A dilemma for human resource management, R\&D Management, 25, 2, I29-I 40.

ARYEE, S. (1992). Antecedents and outcomes of work-family conflict among married professional women: Evidence from Singapore. Human Relations, 45, 8I 3-837.

ARYEE, S. \& Leong, C.C. (I99I). Career Orientations and Work Outcomes Among Industrial R\&D Professionals, Group \& Organization Management, 16, 2, 193-205.

BADAWY, M. (1988), Managing human resources, Research Technology Management, 3 I, 19-35.

BAILYN, L. (1982), Trained as engineers: issues for the management of technical personnel in mid-career, in R. Katz (ed.), Career Issues in Human Resource Management, Prentice Hall, Englewood Cliffs, NJ.

BAILYN, L. (199I). The hybrid career: an exploratory study of career routes in R\&D, Journal of Engineering and Technology Management, 8, I, I- 14.

BARUCH,Y. (1999). Response rate in academic studies: a comparative analysis, Human Relations, 52, 4, 42I-438.

BARUCH, Y. (2004). Managing Careers: Theory and Practice, Pearson, Harlow.

BRIDGES,W. (1994). JobShift: how to prosper in a workplace without jobs, Addison-Wesley, Reading, MA.

CHEN, C., Ford, C., \& Farris, G. (1999). Do rewards benefit the organisation? The effects of reward types and the perception of diverse R\&D professionals, IEEE Transactions on Engineering Management, 46, I, 47-55.

CORDERO, R., DiTommaso, N. \& Farris, G. (1994). Career development opportunities and likelihood of turnover among R\&D professionals, IEEE Transactions on Engineering Management, 4I, 3, 223-233.
CRONBACH, L.J. (I95I). Coefficient alpha and the internal structure of test, Psychometrica, 16, 297-334.

DEBACKERE, K., Buyens, D. \& Vandenbossche, T. (1997). Strategic career development for R\&D professionals: Lessons from field research, Technovation, 17, 2, 53-62.

DELONG, T.J. (1 982). Re-examining the career anchor model, Personnel, 59, 50-6I.

DERR, B. (1980). More about career anchors, Work, Family and the career, Praeger, New York, NY, I66- 188.

FELDMAN, D.C. \& Bolino, M.C. ( 1996), Careers within careers: reconceptualizing the nature of career anchors and their consequences, Human Resource Management Review, 6, 2, 89-I I 2.

FIELD,A. (2000). Discovering statistics using. SPSS for Windows, Sage Publications Ltd, London.

FROHMAN, A.L. (1978). Mismatch Problems in Managing Professionals, Research Management, 2I, 20-25.

GOLDBERG,A.I. \& Shenav,Y.A. ( 1 984). R\&D Career paths: their relation to work goals and productivity, IEEE Transactions on Engineering Management, 3 I, I I I-I I7.

GOULD, S. \& Penley, L. ( 1 984). Career strategies and salary progression: A study of their relationship in a municipal bureaucracy, Organizational Behavior and Human Performance, 34, 244-265.

GREENHOUSE, W. \& Callanan, R. (1994). Career Management, The Dryden Press, Forth Worth, USA.

GUADAGNOLI, E. \& Velicier,W.F. (1988). Relation of sample size to the stability of component patterns, Psychological Bulletin, I03, 265-275.

HALL, D.T. (1996). The career is dead - Long live the career: a relational approach to careers, Jossey-Bass, San Francisco, CA.

IGBARIA, M., Greenhaus, J.H. \& Parasuraman, S. ( 99 I). Career orientations of MIS employees: an empirical analysis", MIS Quarterly, 15, 2, I51-69.

IGBARIA, M., Kassicieh, S. \& Silver, M. (I999). Career Orientations and Career Success among Research, and development and engineering professionals, Journal of Engineering and Technology Management, I6, I, 29-54. 
JEWKES, G., Thompson, P. \& Dalton, G. (1979). How to stifle a technical organisation in ten easy steps, Research Management, 22, I, $12-16$.

LYNN, S.A., Cao, L.T. \& Horn, B.C. (1996). The influence of career stage on the work attitudes of male and female accounting professionals, Journal of Organisational Behaviour, 17, I35-149.

MCCORMICK, K. (1995). Career paths, technological obsolescence and skill formation: R\&D staff in Britain and Japan, R\&D Management, 25, 2, 197-2II.

MILLER, D.B. (1986). Managing Professionals in Research and Development, Jossey Bass, San Francisco.

REALIN, J.A. (1987). Two Track Plans for One Track Careers, Personnel Journal, 66, I, 96-I0I.

REILLY, N.P. \& Orsak, C.L. (1991).A career stage analysis of career and organisational commitment in nursing, Journal of Vocational Behaviour, 39, 31 I-330.

RIFKIN, J. (1995). The end of work: the decline of the global labor force and the dawn of the post-market era, Putnam, New York, NY.

SCHEIN, E.H. (1978). Career dynamics: matching individual and organisational needs. Addison-Wesley, Reading, MA, USA.

SCHEIN, E.H. (1990). Career Anchors, Pfeiffer, San Diego.

SHEPHARD, H.A. (1988). The Dual Hierarchy in Research, in Katz R. (ed.), Managing Professionals in Innovative Organizations, Harper Business New York.

SMITH,J.J. \& Szabo,T.T. (1977). The Dual Ladder: Importance of Flexibility, Job Content and Individual Temperament, Research Management, 20, 20-23.

TAMPOE, M. (1993). Motivating Knowledge Workers - The Challenge for the 1990s, Long Range Planning, 26, 3, 49-55.

TAYLOR, R (1979). Career orientations and intra-occupational choice: a survey of engineering students, Journal of Occupational Psychology, 52.

VON GLINOW, M.A. (1988). The New Professionals: Managing Today's High-Tech Employees, Ballinger Press, Cambridge, Massachusetts.

\section{About the Authors}

Barbara Bigliardi graduated (with distinction) in 2004 in Industrial Engineering and Management at the University of Parma and holds a Ph.D. in Industrial Engineering from the same University in 2008. Since 2005 she has been researcher at the Department of Industrial Engineering of the same University. Her research activities mainly concern innovation management, human resources management and technology transfer. Her research has been published on international journal, such as the European Journal of Innovation Management, Technovation and Leadership \& Organization Development Journal. She is also referee for international journals.

Alberto Ivo Dormio graduated in Mechanical Engineering at the Politecnico of Bari. He holds a Master in Management of Innovation and a Ph.D. in Management Engineering. Since 2006 he is an associate professor at the University of Parma. His research activities mainly concern innovation management, project management and technology transfer. 